\title{
A Study of Phyllostachys bambusoides forma shouzhu Yi Forest Soil N indicators and Enzyme Activity in Spring and Summer
}

\author{
Qianxin Wang ${ }^{1, \text { a }}$, Zhanbiao Yang ${ }^{1, b}$,Yuanxiang Yang ${ }^{1, c^{*}}$, Bowen Sun ${ }^{1, d}$,Zhang \\ Cheng $^{1, e}$ and Xuemei Zhu ${ }^{1, f}$
}

\author{
${ }^{1}$ College of Environment, Sichuan Agricultural University, Chengdu, Sichuan, China, 611130 \\ a986735543@qq.com, byzb195@126.com, c529877087@qq.com, d18683716226@163.com, \\ echengzhang2001@foxmail.com, 'zhubroad@163.com
}

${ }^{*}$ Corresponding author. Qianxin Wang and Zhanbiao Yang contributed equally to this work.

\begin{abstract}
Keywords: Phyllostachys bambusoides forma shouzhu Yi; The Organic matter; Total nitrogen; Available nitrogen; The soil enzyme

Abstract. A study was about the surface soil enzyme activity and $\mathrm{N}$ indicators Variation characteristics of Phyllostachys bambusoides forma shouzhu Yi forest in Liangping, Chongqing Municipality in spring and summer. The results showed that, the forest soil content of organic matter(OM), total nitrogen(TN), available nitrogen(AN) and activity of protease(PRO) performance summer higher than spring, the forest soil activity of urease(URE), catalase(CAT) performance spring higher than summer. Between and among OM, TN, AN performance highly significant positive correlation. Between and among PRO, OM, TN, AN performance a significant or highly significant positive correlation. Between and among URE, CAT, OM, TN, AN performance highly significant negative correlation. The research showed that, the PRO activity could represent nitrogen nutrient condition of $P$. Bambusoides $f$. shouzhu $Y i$ forest soil, in order to improve the sprouting rate and survival quality of bamboo by improve enzyme activity through optimizing forest environment. For spring urease and catalase activity higher and the nitrogen content lower, so we should pay attention to timely replenishment of nitrogen nutrients.
\end{abstract}

\section{Introduction}

Environment and development is one of the major issues of concern to the international community today. Forest can not only effectively improve the environment, reduce environmental pollution, but also play an irreplaceable role in promoting economic and social sustainable development [1]. The results of the seventh national forest resource inventory show that China has 19,545,220,0 hm2 of forest, the forest coverage rate is $20.36 \%$, the forest area ranks fifth in the world, and the forest reserves ranks sixth in the world [2]. Nevertheless, the per capita possession of forest resources in China is still insufficient, and the quality of forest resources is still not high.

Since ancient times, bamboo has been widely used in people's daily life as an important forest resource. The new products with bamboo as raw materials are endless. It has the characteristics of large biomass, short growth cycle, many uses, high ecological and economic value. It is called green "gold" [3]. At present, Phyllostachys bambusoides forma shouzhu Yi is widely used in furniture, paper, packaging, food, medicine, health care, textile, tourism, environmental protection and other industries. Since P. Bambusoides f. shouzhu Yi discovery in 1982, it has been re-established after flowering [4], high-yield cultivation [5], culm form structure [6], bambusoides by rhizome planting [7], characteristics of timber volume [8], sprouting of bamboo and rule of growth [9], mother bamboo within different diameters [10] have been studied, but the research on soil nitrogen content and its enzyme activity in spring and summer of P. Bambusoides $f$. shouzhu Yi forest has not been reported.

So, this paper takes P. Bambusoides $f$. shouzhu $Y i$ forest soil as the research object, and grasp the changes of nitrogen content and enzyme activity in spring and summer, which provides some guidance for rational fertilization, forestation and management of it. 


\section{Materials and Methods}

Research Area Overview. The Zhushan district in the middle section of the Mingyue Mountain in Liangping County, Chongqing City is located between $30^{\circ} 39^{\prime}$ to $30^{\circ} 51^{\prime}$ north latitude and $107^{\circ} 30^{\prime}$ to $107^{\circ} 41^{\prime}$ east longitude. The altitude $500 \mathrm{~m}-1100 \mathrm{~m}$, and the soil belongs to mountain yellow soil. The average annual temperature of $14-16{ }^{\circ} \mathrm{C}$, a frost-free period of about 250 days, an average annual precipitation of $1200-1400 \mathrm{~mm}$, and a relative humidity of $85 \%$. It belongs to the subtropical monsoon climate zone [5].

Experimental Materials. P.bambusoides belong to Phyllostachys which belong to Gramineae's Bambusoideae. P. Bambusoides $f$. shouzhu Yi is its variation. P. Bambusoides $f$. shouzhu Yi is a shallow-rooted uniaxial loose bamboo with a stalk of up to $20 \mathrm{~m}$ and a diameter of $4-13 \mathrm{~cm}$. The stalk can be up to $50 \mathrm{~cm}$ in length, mainly distributed in eastern Sichuan, Chongqing and southern Hunan.It is the fine large diameter bamboo species after Phyllostachys edulis [11].

Experimental Method. According to the field investigation in the research area, three sample of $10 \mathrm{~m} \times 10 \mathrm{~m}$ were set up under the premise of soil type, slope, slope position and altitude, and the bamboo forest with representative and less human interference was selected. The sampling place is located at $30^{\circ} 45^{\prime} 53.6^{\prime \prime}$ north latitude and $107^{\circ} 36^{\prime} 18.0^{\prime \prime}$ east longitude. Sampling in spring and summer, on April 15, 2017 and July 15, 2017. Take P. Bambusoides f. shouzhu Yi forest 0-20 cm soil. In each sampling unit, take the soil sample according to the serpentine method (avoiding the roadside and the ground angle), collect the surface soil with a small shovel, mix the soil in each sampling unit to form a mixed sample (about $5 \mathrm{~kg}$ ) and bring it back to the laboratory. The basic outline of each sampling place is shown in Table 1.

Table 1 General situation of different forest stands

\begin{tabular}{cccccccc}
\hline $\begin{array}{c}\text { Sample } \\
\text { number }\end{array}$ & $\begin{array}{c}\text { Altitudes } \\
/ \mathrm{m}\end{array}$ & Soil types & $\begin{array}{c}\text { Culm } \\
\text { number }\end{array}$ & $\begin{array}{c}\text { Slope }^{\circ} \\
\text { Slope } \\
\text { position }\end{array}$ & $\begin{array}{c}\text { Average } \\
\text { DBH } / \mathrm{mm}\end{array}$ & $\begin{array}{c}\text { Average } \\
\text { height } / \mathrm{m}\end{array}$ \\
\hline 1 & 858 & Mountain yellow soil & 77 & 25 & Mid-uphill & 73.18 & 15.20 \\
2 & 859 & Mountain yellow soil & 78 & 25 & Mid-uphill & 78.50 & 16.13 \\
3 & 862 & Mountain yellow soil & 85 & 23.5 & Mid-uphill & 71.81 & 15.10 \\
\hline
\end{tabular}

Measuring Indicators and Methods. These indicators and methods shown in Table 2.

Table 2 Measuring indicators and methods

\begin{tabular}{|c|c|c|c|c|c|c|}
\hline Indicators & $\begin{array}{l}\text { Organic matter } \\
\qquad(\mathrm{OM})\end{array}$ & $\begin{array}{l}\text { Total } \\
\text { nitrogen } \\
(\mathrm{TN})\end{array}$ & $\begin{array}{c}\text { Alkali- } \\
\text { hydrolyzable } \\
\text { nitrogen }(\mathrm{AN})\end{array}$ & $\begin{array}{l}\text { Urease } \\
\text { (URE) }\end{array}$ & $\begin{array}{l}\text { Protease } \\
\text { (PRO) }\end{array}$ & $\begin{array}{l}\text { Catalase } \\
\text { (CAT) }\end{array}$ \\
\hline Methods & $\begin{array}{c}\text { Potassium } \\
\text { dichromate heating } \\
\text { oxidation-volumetric } \\
\text { method [12] }\end{array}$ & $\begin{array}{l}\text { Semi-Micro- } \\
\text { Kjeidahl } \\
\text { method [12] }\end{array}$ & $\begin{array}{l}\text { Alkali-diffusion } \\
\text { method [12] }\end{array}$ & $\begin{array}{l}\text { Indophenol } \\
\text { blue } \\
\text { colorimetric } \\
\text { method [13] }\end{array}$ & $\begin{array}{c}\text { Ninhydrin } \\
\text { colorimetry } \\
{[13]}\end{array}$ & $\begin{array}{c}\text { Potassium } \\
\text { [13] }\end{array}$ \\
\hline
\end{tabular}

Statistical Analyses. Data processing and statistical analysis using Excel and DPS.

\section{Result and Discussion}

Soil N Characteristics of P. Bambusoides $f$. shouzhu Yi Forest in Spring and Summer. It can be seen from Table 3 that the soil OM, TN and AN content in the surface soil of P. Bambusoides $f$. shouzhu $Y i$ in spring are $40.01 \mathrm{~g} / \mathrm{kg}, 2.49 \mathrm{~g} / \mathrm{kg}$ and $157.90 \mathrm{mg} / \mathrm{kg}$, respectively, and the OM, TN and AN content in the surface soil of $P$. Bambusoides $f$. shouzhu $Y i$ forest in summer are $67.21 \mathrm{~g} / \mathrm{kg}, 3.86 \mathrm{~g} / \mathrm{kg}$, and $215.48 \mathrm{mg} / \mathrm{kg}$, respectively. The content of these three components was significantly different in spring and summer, and the overall performance spring higher than summer. There are two reasons for this: On the one hand, bamboo sprouting absorb lots of nutrients in spring, which results in lower soil nutrient content in spring. On the other hand, high temperature and high humidity in summer, which is beneficial to the decomposition of organic matter by microorganisms and enzymes.

$\mathrm{OM}$ of soil and soil minerals together serve as a source of forest nutrients and have a positive impact on soil physical and chemical properties. Wenxuan Li and other studies on forest soils show 
that the OM content is high, the AN content is also high, and have the great ability of potential nitrogen supply, which is beneficial to the absorption of various nutrients by plants [14]. The high content of organic matter in this study area contributes to the growth of bamboo. Mingyan Jiang et al.'s research on Neosino calamus affinis showed that there was a significant correlation between and among OM of soil ,stalk height ,stalk weight [15].

TN of Soil reflects total soil nitrogen. Mingyan Jiang et al.'s research on Neosino calamus affinis showed that there was a significant or highly significant correlation between and among soil TN content, stalk height, wall thickness, stalk weight [15].

AN of Soil is a nutrient that can be directly absorbed by plants or converted into plant absorption in a short period of time, which can better reflect the recent nitrogen supply status of the soil. Zhiqin Gao et al. have shown that in spring and summer, the content of alkaline nitrogen in the soil of the uncultivated Phyllostachys edulis forest is higher than autumn and winter [16].

The results of this experiment showed that the surface OM, TN and AN content of spring and summer $P$. Bambusoides $f$. shouzhu $Y i$ forest belonged to the first level of the national soil census nutrient grading standard, which was beneficial to bamboo forest growth in general.

Table 3 The soil $\mathrm{N}$ indicators changes in spring and summer

\begin{tabular}{ccc}
\hline Indicators & \multicolumn{3}{c}{ Season } \\
\cline { 2 - 3 } & Spring & Summer \\
\hline $\mathrm{OM} /\left(\mathrm{g} \cdot \mathrm{kg}^{-1}\right)$ & $40.01 \pm 4.04 \mathrm{~b}$ & $67.21 \pm 4.49 \mathrm{a}$ \\
$\mathrm{TN} /\left(\mathrm{g}^{\mathrm{kg}} \mathrm{kg}^{-1}\right)$ & $2.49 \pm 0.21 \mathrm{~b}$ & $3.86 \pm 0.12 \mathrm{a}$ \\
$\mathrm{AN} /\left(\mathrm{mg} \cdot \mathrm{kg}^{-1}\right)$ & $157.90 \pm 2.48 \mathrm{~b}$ & $215.48 \pm 1.42 \mathrm{a}$ \\
\hline
\end{tabular}

(Note:Values followed by a different lowercase or capital letter within each row are significantly different at 0.05 and 0.01 probability levels,respectively. The same below.)

Characteristics of Soil Enzyme Activity in P. Bambusoides $f$. shouzhu Yi forest in Spring and Summer. It can be seen from Table 4 that the URE, PRO and CAT activities in the surface soil of $P$. Bambusoides $f$. shouzhu $Y i$ forest in spring are $0.20 \mathrm{mg}\left(\mathrm{NH}_{3}-\mathrm{N}\right) /(\mathrm{g} \cdot \mathrm{d}), 0.012 \mathrm{mg}\left(\mathrm{NH}_{2}-\mathrm{N}\right) /(\mathrm{g} \cdot \mathrm{d})$, $45.35\left(0.1 \mathrm{~mol} / \mathrm{LKMnO}_{4}\right) /(\mathrm{min} \cdot \mathrm{kg})$, respectively. In summer, they are $0.12 \mathrm{mg}\left(\mathrm{NH}_{3}-\mathrm{N}\right) /(\mathrm{g} \cdot \mathrm{d}), 0.029$ $\mathrm{mg}\left(\mathrm{NH}_{2}-\mathrm{N}\right) /(\mathrm{g} \cdot \mathrm{d}), 40.58 \mathrm{ml}\left(0.1 \mathrm{~mol} / \mathrm{LKMnO}_{4}\right) /(\mathrm{min} \cdot \mathrm{kg})$, respectively. Compared with the soil enzyme activities of bamboo forest such as Phyllostachys violasces and Dendrocallamus latiflorus $[17,18,19]$, the URE activity in the surface soil of $P$. Bambusoides $f$. shouzhu Yi forest is higher, while the PRO and CAT activities are lower, which needs to be improved. The activities of URE, PRO and CAT in P. Bambusoides $f$. shouzhu Yi forest were significantly different in spring and summer. The PRO activity performance summer higher than spring, which was the same as that of OM, TN and AN. The activities of USE and CAT performance spring higher than summer, which was consistent with Baoxian Tao 's research on the seasonal changes of soil enzyme activity in Phyllostachys edulis forest [20]. The change rule of USE and CAT activities were opposite to those of soil OM, TN and AN. The reason may be that sprouting of bamboo in spring consume a lot of soil nutrients, or due to the forest has high humidity in summer, the enzyme activity is inhibited for poorly ventilated soil.

Table 4 The soil enzyme activity changes in spring and summer

\begin{tabular}{ccc}
\hline Indicators & \multicolumn{3}{c}{ Season } \\
\cline { 2 - 3 } & Spring & Summer \\
\hline $\mathrm{URE} / \mathrm{mg} \cdot(\mathrm{g} \cdot \mathrm{d})^{-1}$ & $0.20 \pm 0.00027 \mathrm{a}$ & $0.12 \pm 0.033 \mathrm{~b}$ \\
$\mathrm{PRO} / \mathrm{mg} \cdot(\mathrm{g} \cdot \mathrm{d})^{-1}$ & $0.012 \pm 0.0031 \mathrm{~b}$ & $0.029 \pm 0.016 \mathrm{a}$ \\
$\mathrm{CAT} / \mathrm{ml} \cdot(\mathrm{min} \cdot \mathrm{kg})^{-1}$ & $45.35 \pm 0.12 \mathrm{a}$ & $40.58 \pm 1.49 \mathrm{~b}$ \\
\hline
\end{tabular}

Correlation between Soil $\mathbf{N}$ and Its Enzyme Activities. As can be seen from Table 5, there is a significant or highly significant correlation between other indicators except for the CAT and PRO. CAT and PRO are not significantly correlated. Among them, there was a highly significant positive correlation between $\mathrm{OM}, \mathrm{TN}$ and $\mathrm{AN}$. OM, TN, USE,CAT and AN performance a highly significantly negatively correlated. PRO OM, TN and AN performance a significant or highly significant positive correlation, which is consistent with the results of surface soil PRO research in 
Phyllostachys edulis forest and Phyllostachys violasces forest etc. [17,18,19]. Indicating that PRO is an ideal indicator of fertility. Jiasen $\mathrm{Wu}$ and other studies have shown that the correlation between PRO of soil and crude growth of Phyllostachys edulis is highly significant[21]. Forest soil enzymes are regarded as indicators of sensitivity and reliability, participating in energy flow and material circulation in forest ecological processes [22]. However, the factors affecting soil enzyme activity are complex. Microbial species, water, gas and heat conditions in soil, $\mathrm{pH}$, bamboo age, nutrient, pollution degree, etc. All of this affect the soil enzyme activity significantly, so needs further study.

Table 5 Relations between enzyme activity and $\mathrm{N}$ indicators of the soil

\begin{tabular}{ccccccc}
\hline Indicators & OM & TN & AN & URE & PRO & CAT \\
\hline OM & 1.000 & $0.991^{* *}$ & $0.962^{* *}$ & $-0.718^{* *}$ & $0.532^{*}$ & $-0.859^{* *}$ \\
TN & & 1.000 & $0.965^{* *}$ & $-0.762^{* *}$ & $0.551^{*}$ & $-0.882^{* *}$ \\
AN & & & 1.000 & $-0.806^{* *}$ & $0.639^{* *}$ & $-0.854^{* *}$ \\
URE & & & & 1.000 & $-0.826^{* *}$ & $0.601^{* *}$ \\
PRO & & & & 1.000 & -0.303 \\
CAT & & & & & & 1.000 \\
\hline
\end{tabular}

(**Represents the correlation coefficient between soil enzyme activity and soil fertility index $\mathrm{P}<0.01$, reaching a highly significant level. * represents the correlation coefficient between soil enzyme activity and soil fertility index $\mathrm{P}<0.05$, reaching a significant level)

\section{Conclusions and Suggestions.}

In summary, the soil OM, TN and AN content in the surface soil of P. Bambusoides f. shouzhu Yi forest in spring and summer were significantly diversity from URE, PRO and CAT activities, which fully indicated the strong influence of the season on soil nitrogen content and enzyme activity. The contents of $\mathrm{OM}, \mathrm{TN}$ and AN performance summer higher than spring generally. USE activity: spring>summer, PRO activity: summer>spring, CAT activity: spring>summer. The analysis showed that, between and among OM, TN, AN performance highly significant positive correlation, between and among PRO, OM, TN, AN performance a significant or highly significant positive correlation, between and among URE, CAT, OM, TN, AN performance highly significant negative correlation. Therefore, in the evaluation of soil fertility level, USE, PRO and CAT activity characteristics are important indicators that cannot be ignored.

At present, the research on the soil enzyme activity of $P$. Bambusoides $f$. shouzhu Yi forest has not been reported yet. Some studies provide theoretical basis for high-yield and high-yield production of $P$. Bambusoides $f$. shouzhu $Y i$ forest through bambusoides by rhizom, etc., which have certain restrictions on the area where P. Bambusoides f. shouzhu $Y i$ is planted. In this paper, the changes of soil nitrogen nutrients and enzyme activities before and after bamboo germination were studied, which provided a theoretical basis for improving the sprouting rate and promoting the growth of materials: (1) Adding cover to the bamboo forest surface. This study shows that the season has a strong influence on nitrogen nutrient and enzyme activity. Therefore, according to the seasonal changes, do the relevant insulation and maintenance measures timely. (2) Turning up the earth and digging drainage. The results of this study indicate that due to excessive humidity in summer, bamboo root have strong water retention, lead to low soil breathability and reduced enzyme activity. Therefore, depending on the specific situation, the drainage can be properly constructed, and turning up the earth timely after bamboo shoots grow up. (3) Adjust the bamboo forest structure and arrange the planting density reasonably. Although the bamboo forest nutrient content of P. Bambusoides $f$. shouzhu Yi forest in this study is high, the plant density is sparse, and the nutrient advantage of the forest itself is not fully utilized. Therefore, scientific planting density should be calculated to increase economic value, in artificial planting. (4) The other nutrients and corresponding enzyme activities of $P$. Bambusoides $f$. shouzhu $Y i$ forest soil should continue to be studied to provide guidance for bamboo farmers to fertilize. At the same time, during the fertilization process, the surface of the bamboo forest should not be fertilized, It is better to fertilize in a hole that near the roots. 


\section{References}

[1] C.Y. Zhou: The Farmers Consultant Vol. 36 (2018),p. 108.

[2] C.G. Zhi and D.M. Zheng: Forest Resources Management Vol. 40 (2011), p. 37.

[3] Ziguangge Vol. 26 (2018), p. 87.

[4] H.R. Qi: Bamboo Research (1989), p. 60.

[5] Z.B. Wen, Z.F. Huang and H.Y. Ding: World Bamboo and Rattan Vol. 6 (2008), p. 30.

[6] X.H. Gan, J. Zou, Z.B. Wen and H.Y. Ding: Journal of Zhejiang Forestry Science and Technology Vol. 29 (2009), p. 48.

[7] Z.B. Wen, H.Y. Ding, Z.F. Huang and Y.J. Gao: World Bamboo and Rattan Vol. 8 (2010), p. 16.

[8] C.B. Tang, X.H. Gan, Z.B. Wen, Y.J. Gao and H.Y. Ding: World Bamboo and Rattan Vol. 8 (2010), p. 4.

[9] D.Y. Lv, S.Yu, F.Z. Huang, Z.B. Wen, Y.L. Ding and F.S. Wang: China Forestry Science and Technology Vol. 26 (2012), p. 76.

[10]L. Tong, Y.J. Gao, B. Li, L.J. Chen and Y.H. Geng: Journal of Anhui Agricultural Sciences Vol. 57 (2017), p. 158.

[11] Flora Republicae Popularis Sinica (Science Press, Beijing 1996).

[12] S.D. Bao: Soil and Agriculture Chemistry Analysis (China Agriculture Press, Beijing 1988).

[13] S.Y. Guan: Soil Enzyme and Research Method (China Agriculture Press, Beijing 1986).

[14]W.X. Li: Forestry Prospect and Design Vol. 28 (2008), p. 107.

[15]M.Y. Jiang, Q.B. Chen, Z.H. Luo and H. Liu: Journal of Sichuan Agricultural University Vol. 29 (2011), p. 482.

[16]Z.Q. Gao and M.Y. Fu: Journal of Bamboo Research Vol. 27 (2008), p. 25.

[17]Z.H. Tu, R. Pan, R.F. Lu, X.Y. Hong, H.L. Chen, J.D. Jun and Y.S. Zheng: Journal of Fujian Agriculture and Forestry University (Natural Science Edition) Vol. 41 (2012), p. 243.

[18]P.K. Jang, Y.W. Yu, L.Q. Zhang and X.W. Xu: Journal of Zhejiang Forestry College Vol. 17 (2000), p. 132.

[19]Z.H. Tu, X.Y. Hong, R. Pan, L.G. Chen, J.D. Rong and Y.S. Zheng: Acta Agriculturae University Jiangxiensis Vol. 34 (2012), p. 511.

[20]B.X. Tao, J.C. Zhang, Y.C. Yu and R.L. Cong: Ecology and Environmental Sciences Vol. 19 (2010), p. 2349.

[21]J.S. Wu, M.Y. Hu, T.F. Cai and G.J. Yu: Journal of Bamboo Research Vol. 25 (2006), p. 3.

[22] G.L. Li, Y. Liu, J. Gan, B. Guo and X.U. Yang: Frontiers of Forestry in China Vol. 3 (2008), p. 286. 